\title{
A Reconquista: entre o debate historiográfico e a avaliação de uma realidade tardo-medieval
}

The Reconquista: historiographic debate and the evaluation of a late medieval reality

Marcella Lopes Guimarães*

\section{Resumo}

Este artigo tem como foco a discussão do conceito de Reconquista em três desdobramentos: no diálogo com os estudos medievais; no recurso às crônicas tardo-medievais portuguesa e castelhana, a saber as escritas por Gomes Eanes de Zurara e a Crónica de D. Juan II, e, por fim, na mediação do debate para o estudo da História Medieval no ambiente da escola, a fim de fazer convergir a análise e o recurso aos documentos de forma significativa para a construção do conhecimento histórico entre os estudantes.

Palavras-chave: Reconquista; Baixa Idade Média; Península Ibérica.

\section{Abstract}

This article focuses on the concept of Reconquista in three specific directions: the dialogue with medieval studies; the use of chronicles during the late-medieval Portuguese and Castilian period, namely the writings by Gomes Eanes de Zurara and the Chronicle of D. Juan II, and finally, in the mediation of the debate for the study of Medieval History in the school sphere, in order to make the analysis and use of documents converge in a meaningful way for the construction of historical knowledge by the students.

Keywords: Reconquista; Late Middle Age; Iberian Peninsula.

Em 1415, sete séculos depois da chegada dos mouros à Península Ibérica pelo norte de África, os portugueses tomaram violentamente a praça de Ceuta. Portugal já não era mais palco de combates identificados com a Reconquista havia pelo menos quase dois séculos; vivia um período de tréguas com Castela, que, por sua vez, ainda tinha seus mouros para combater, no reino de Granada.

A conquista de Ceuta tem importância diversa para os reinos ibéricos e é reportada também de forma bastante diferente nos documentos que orientam

\footnotetext{
* Doutora em História pela Universidade Federal do Paraná (UFPR). Professora Associada da UFPR e Vice-Coordenadora do Programa de Pós-Graduação em História da UFPR. Curitiba, PR, Brasil.marcella974@gmail.com
} 
este artigo. Na Crónica da Tomada de Ceuta do português Gomes Eanes de Zurara é o acontecimento primordial, enquanto na Crónica del serenísimo Príncipe Don Juan, segundo rey deste nombre en Castilla y en Leon é fragmento do capítulo oitavo concernente ao ano e, levando-se em conta que a crônica documenta 46 anos de reinado do rei de Castela D. Juan II, a notícia da conquista portuguesa parece ínfima na economia do texto castelhano. No mesmo século em que a tomada do reino de Granada (1492) encerraria a história do Al-Andaluz, os documentos mencionados conferem importantes tonalidades para a percepção de como a campanha da Reconquista perdura no fim da Idade Média peninsular.

\section{Documentação}

Antes de confrontarmos o tema no universo documental, interessa compreender as características das fontes e dos sujeitos de sua enunciação; isso é fundamental para a proposta que este artigo enseja no seu terceiro item. Gomes Eanes de Zurara foi guarda da livraria do rei Afonso V (reinado de 1438 a 1481) e sucedeu a Fernão Lopes em 1454 como Guarda-Mor da Torre do Tombo e cronista régio (Gomes apud Lanciani; Tavani, 2000, p.687). É autor de quatro crônicas, sendo a Crónica da Tomada de Ceuta a sua primeira, escrita em torno de 1449, ou seja, mais de 30 anos depois dos acontecimentos narrados. Alguns participantes da campanha ainda estavam vivos, mas o feito já começava a arrefecer na memória. O desastre de Tânger, espécie de contrafesta de Ceuta, já tinha sucedido, bem como a morte do rei D. Duarte. Em 1449 ocorreu a Batalha de Alfarrobeira, acontecimento que macula a imagem positiva da "ínclita" geração, com a morte em campo do infante Pedro, Duque de Coimbra e sogro do rei Afonso $\mathrm{V}$, depois de uma regência tomada à mãe do rei, a rainha Leonor, e dos conflitos entre as casas nobiliárquicas do reino português, incluindo disputas entre os irmãos, filhos de D. João I. Zurara escreveu sobre a conquista, mas tinha memória e experiência do seu inverso. D. Fernando, o infante santo, já morrera em África, depois de longo cativeiro, que a crônica de Frei João Álvares documenta. ${ }^{1}$

A Crónica da Tomada de Ceuta pode ser considerada a terceira parte da Crónica de D. João I, ou seja, a continuação direta do trabalho de Fernão Lopes, sobretudo levando-se em conta que o labor desse cronista, no caso do primeiro 
monarca de Avis, estava longe de ter sido concluído. Isso quando constatamos a longevidade do reinado (48 anos!) e os acontecimentos compreendidos no texto lopeano. A primeira crônica de Zurara (doravante CTC) é uma crônica que continua decerto pelo reinado de D. João I e, sem deixar de ser uma crônica régia, é sobretudo uma crônica acontecimental, ou seja, tem um fato determinado como núcleo. Zurara não escreve sem repertório. Beneficiou-se de uma longa tradição ibérica, que passou da crônica geral às crônicas particulares, sejam elas régias ou senhoriais. Pode "inovar" no privilégio do fato: a conquista de Ceuta.

É Zurara, aliás, quem nos dá detalhes do trabalho de Fernão Lopes, no seu $3^{\circ}$ capítulo. Vemos o velho cronista a realizar uma verdadeira prospecção para narrar: "E assim foi necessário ao dito Fernão Lopes de andar por todas as partes do reino para haver cumprida informação do que havia de começar" (CTC, p.45). O que isso significa? Que para além do acontecimento da tomada da cidade, o documento revela outras significativas relações sobre a escrita da história no Baixo Medievo. ${ }^{2}$ Como o substituto de Fernão Lopes contextualiza a sua própria escrita? Ao revelar a pesquisa de Lopes, incluindo as demandas do próprio rei D. Duarte em busca de documentos para fundamentar esse grande empreendimento português das letras, Zurara observa que seu sucessor não pôde ir além daquelas tréguas que referimos, antessala da própria campanha de Ceuta. É Afonso V quem retoma o projeto:

soube como os feitos de seu avô ficaram por acabar, considerando como o tempo escorregava cada vez mais, e que, tardando de serem escritos, poderiam as pessoas que ali foram falecer, por cuja razão se perderia a memória de tão notáveis cousas, porém mandou a mim, Gomes Eanes de Zurara, seu criado, que me trabalhasse de as ajuntar e escrever per tal guisa, que, ao tempo que se houvessem de ordenar em crónica, fossem achadas sem falecimento. (CTC, p.45)

Ressaltamos o emprego da primeira pessoa do singular, não como novidade, na medida em que a individualidade já se inscreve nas narrativas medievais pelo menos 2 séculos antes da existência do cronista Zurara, mas como afirmação do sujeito que escreve História, do seu labor específico: em relação ao passado que constitui o seu "emprego", seus métodos e a ameaça do tempo aos acontecimentos que devem ser narrados; o presente da sua voz e o futuro que o texto ambiciona como reserva e lição. 
Toda a luta entre portugueses e castelhanos no último quartel do século XIV, narrada por Fernão Lopes, ressuma a pecado nas páginas de Zurara, afinal foram lutas entre cristãos. O cronista chega a afirmar que João I de Portugal pelejava para buscar a paz, por mais contraditória e cheia de trágicas ressonâncias que seja hoje essa relação. Depois das tréguas com Castela, o reino português viveria em estado de bonança (pelo menos do ponto de vista do texto), até o rei ter a ideia de, para servir a Deus, requerer participação nas guerras contra Granada. O infante castelhano Fernando de Antequera alude a tréguas que, por sua vez, foram firmadas com o rei mouro, talvez para rechaçar o “auxílio" do português, e D. João lembra que seus filhos ainda não haviam sido adubados, ou seja, feitos cavaleiros. É a antessala de Ceuta, uma campanha cavalheiresca de Reconquista, do ponto de vista da narrativa.

A Crónica del serenísimo Príncipe Don Juan, segundo rey deste nombre en Castilla y en Leon foi uma realização de muitas mãos. A primeira parte, produzida, entre 1406 e 1420, cobre acontecimentos do período em questão e foi escrita por Álvaro García de Santa María. Um novo cronista substituiu o primeiro na narrativa dos acontecimentos até cerca de 1438, talvez o poeta Juan de Mena. Depois de 1435, porém, não se sabe ao certo quem continuou o texto até que Fernán Perez de Guzman, sobrinho de Pero López de Ayala, tomou a tarefa de compilar a crônica e continuá-la.

Todos os envolvidos na elaboração desse documento extraordinário no que se refere à sua robustez, à diversidade de relações contempladas, métodos de escrita e valores, tinham uma longa tradição de que se servir:

Alfonso X había marcado la pauta para la historiografía en castellano; el modelo alfonsí será seguido, imitado o reelaborado (y refundido) por numerosos autores a lo largo de los siglos XIV y XV, para quienes la historia continuará centrándose em figuras de los reys, representantes de su pueblo, en torno a las cuales se fijan los hechos dignos de ser recordados. (Alvar; Mainer; Navarro, 2011, p.198)

O modelo afonsino, entretanto, é o das crônicas gerais, que remontam à criação do homem e manifestam o destino providencialista da História. Esse modelo constitui o repertório de outro gênero textual, o das crônicas régias, que circunscrevem a narrativa a reinados específicos. Ainda que sejam identificadas pelo monarca, não podemos afirmar que as crônicas régias são narrativas biográficas, embora o medievo tenha dado azo a essas também (Funes, 
2008; Guimarães, 2012b, 2012c). As crônicas régias são narrativas que registram acontecimentos compreendidos (e selecionados) em um reinado. Em Castela, por exemplo: o reinado de Pedro Cruel, Henrique Trastâmara, D. Juan I, Henrique III e Juan II (e ainda outros). Excetuando-se a Crónica del serenísimo Príncipe Don Juan, segundo rey deste nombre en Castilla y en Leon que nos guia no ensaio, os outros reinados citados, de Pedro a Henrique III, foram objeto da escrita do cronista castelhano Pero López de Ayala, por sinal grande fonte do português Fernão Lopes.

Pero López de Ayala não era um homem de gabinete, como Fernão Lopes. Era um cavaleiro no exercício da função, foi chanceler maior do reino e escrevia também. Escrevia prosa e poesia! ${ }^{3}$ Ayala participou dos acontecimentos que narrou; foi mesmo feito cativo na Batalha de Aljubarrota (1385) e ficou por meses em Portugal, até seu resgate ser pago. Ayala morre quase ao mesmo tempo que seu último protagonista, Henrique III, pai do "serenísimo Príncipe Don Juan, segundo rey deste nombre en Castilla y en Leon".

O Chanceler maior de Castela redefiniu a escrita da história em seu reino. Quando Álvaro García de Santa María começa a escrever a crônica de Juan II tem um largo repertório de que servir, bem como o refundidor final do texto também, não pode ser mero detalhe que tenha sido um sobrinho de Ayala a terminar a tarefa, a partir de outro texto, um sumário de Pero Carrillo de Albornoz (Cadaval apud CDJII, p.274). Lorenzo Galindez de Carvajal, responsável pelo prefácio e endereçamento do texto ao rei Carlos V (1500-1559), entretanto, alude ao trabalho de García de Santa María em um aspecto relevante: no segmento pelo qual foi responsável, reconta-se mais tudo aquilo que concerne a Fernando de Antequera, que haveria de se tornar rei de Aragão, que qualquer outro assunto. Carvajal menciona até mesmo um equívoco advindo do fato: um cavaleiro teria presentado a Fernando o Católico, avô de Carlos V, com a crônica, pois pensou que o Fernando de que falara sobejo García de Santa María era o marido da rainha Isabel a Católica.

Ao lado da constatação de que é Fernando de Antequera o protagonista do texto de Álvaro García de Santa María, sobressaem os negócios da tutoria de Juan II e a campanha contra Granada. O cronista teria se beneficiado do fato de ter servido ao infante Fernando, tio de Juan II. Assim, o segmento que interessa mais particularmente a esta reflexão está, pois, identificado justamente com a escrita de Santa María e do cronista anônimo, que lhe sucedeu, 
muito embora não se possa ignorar que essas partes podem ter sido objeto de alterações realizadas por Fernán Perez de Guzman.

Carvajal menciona um fato interessante sobre a Crónica del serenísimo Príncipe Don Juan, segundo rey deste nombre en Castilla y en Leon (doravante CDJII); afirma que havia uma cópia da crônica na câmara da rainha Isabel, avó de Carlos V, e que ela bem considerava o trabalho de Guzman: "su Alteza tenia esta Crónica de Fernan Perez en mucho precio y estimation, por mas aucténtica y aprobada" (Cadaval apud CDJII, p.274). É preciso reconhecer que o cronista mal dá conta de narrar o nascimento de Isabel, $3^{\circ}$ capítulo do ano de 1451 (CDJII, p.673), referindo, entretanto, já o fato de a infanta que nascia ter se tornado princesa (herdeira) e rainha. Levando-se em conta a imagem construída de D. Juan II, pai da rainha, nesse documento, que narra e descreve sobejos exemplos do quanto o rei foi cativo dos seus preferidos e às vezes literalmente, esses contraexemplos seriam tão importantes quanto o bom exemplo para os príncipes que são seu público alvo. Outro elemento relevante é a consideração crítica de Cadaval sobre o texto em si, ou seja, a sua diferença de estilo e opinião, já que alguns cronistas calaram outros. Cadaval sintetiza essa diversidade com a consideração do que seria mais apropriado à tarefa: "Es verdade quel oficio de cronista como el del testigo é escribano, no es juzgar y glosas los hechos, mas solamente recontarlos como pasaron" (Cadaval apud CDJII, p.274). Guzman não está isento das críticas de Cadaval que, entretanto, reconhece a sua nobreza, prudência e preocupação com a verdade. Ganha destaque o pequeno detalhe da crônica na câmara da rainha, afinal ela aprovara o trabalho de Guzman, e Cadaval não pode esquecer que a rainha é avó do rei a quem se dirige.

Em 1489, muito próximo a realizar de forma exitosa seu intento (de conquista de Granada), Fernando o Católico, marido de Isabel, reúne a argumentação de séculos que compõe o conceito de Reconquista ao aludir ao senhorio legítimo dos cristãos na região; à linhagem de defensores desde Pelayo, a qual ele Fernando integra, à justiça e ao direito de prosseguir em uma campanha de expulsão daqueles que haviam "violentamente usurpado" o território (apud García Fitz, 2009, p.171).

A Crónica del serenísimo Príncipe Don Juan, segundo rey deste nombre en Castilla y en Leon dada a sua notória robustez e diversidade pode ser dividida em dois grandes grupos: acontecimentos da menoridade de Juan II até 1419 e 
do reinado efetivo, até 1453. Mas esse último, do reinado efetivo, ainda pode ser redividido, levando-se em conta a "tutela" imposta ao rei por diversos agentes: os infantes de Aragão, Álvaro de Luna e o rei de Narrava e Aragão, também Juan II (pai de Fernando, o Católico). Para os propósitos deste texto, é o período da tutela o mais prolífero, pois os negócios da Reconquista são ensombrados no reinado efetivo pelos inúmeros problemas enfrentados pelo rei de Castela em ver reconhecida e ter respeitada a sua autoridade régia. Já a CTC, que tem um acontecimento em seu núcleo, embora agregue outros, pode ser dividida entre os preparativos da viagem e a conquista em si.

\section{No SÉculo XV, COMO SE DÁ CONTINUIDADE À RECONQUISTA?}

Um dos debates mais prolíferos dos estudos medievais é o que se trava a respeito do conceito de Reconquista. Essa palavra é estranha às fontes do período, ainda que alguns verbos empregados nos documentos, com o sentido de recuperar, resgatar etc., evoquem-na. A ausência da denominação nas fontes longe de manietar a exploração do tema, antes favorece a sua fortuna historiográfica. Abordar a Reconquista é chamar a atenção para a historicidade e para a transformação dos conceitos, um excelente exercício para historiadores de diferentes repertórios e gerações.

A concepção e a difusão relativamente recentes do conceito, ou seja, a partir do século XIX, exigem, entretanto, uma ponderação. Em correto balanço historiográfico, Francisco García Fitz recua às obras de Menéndez Pidal e Claudio Sánchez Albornoz, onde se revela o sentido nacionalista da Reconquista como uma "empresa común de todos los españoles, en el curso de la cual un grupo disperso de reinos cristianos, tras varios siglos [oito séculos] de "lucha nacional y religiosa" (García Fitz, 2009, p.145) vence o "invasor" mouro definitivamente, no século mesmo em que se escrevem as fontes que guiam este ensaio. García Fitz observa que essa vertente de compreensão fez da Reconquista o mito originário do nacionalismo espanhol (2009, p.146). O mesmo historiador, entretanto, pede prudência na relação imediata dessa noção com o franquismo e exemplifica com a evocação da trajetória pessoal de Cláudio Sánchez Albornoz.

As pesquisas de Abilio Barbero e Marcelo Vigil escreveriam uma ruptura com a interpretação tradicional e nacionalista do conceito, ao aludir que, no 
norte, entre as Astúrias e a Cantábria, nem a dominação romana teria sido jamais efetiva, nem os visigodos teriam logrado estender-se na região sem oposição. Hodiernamente, essas conclusões foram confrontadas por Manuel González Jiménez (García Fitz, 2009, p.162; González Jiménez, 2003) e outros historiadores. As conclusões de Barbero e Vigil motivariam, todavia, uma questão: como esse grupo nortenho de "oposição" se arvoraria em restaurador e reconquistador dos valores dos visigodos, em nome da Cristandade? Os autores aludem a razões socioeconômicas que já estariam postas nos confrontos dos asturianos, cantábricos e gascões contra os visigodos. Esses conflitos teriam continuidade nas mesmas bases contra os muçulmanos. García Fitz menciona ainda a interessante posição de José Luis Martín, que também encontra respaldo no pensamento de Richard Fletcher (2002) de que a Reconquista teria se iniciado não no dia seguinte ao Guadalete (711), mas sim com a migração dos clérigos moçárabes para o norte, um século e meio depois da vitória cristã de Covadonga (722). O fato é que, com o passar dos anos, entre defensores e detratores do conceito, todos seguiram utilizando-o. A explicação seria fundada na sua generalização e difusão?

É possível. Que o conceito se converteu em instrumento operativo, a sua longevidade e sobrevivência em meio às mais acirradas disputas historiográficas o provam. Ora, então como podemos compreender a Reconquista afinal? Como um feixe de elementos e relações de longa duração que foram permeados por variados influxos, no tempo. Entre os elementos e relações reunidos nesse feixe, compreendem-se a expansão territorial; a substituição de poder político dos muçulmanos para os cristãos, com "integración de los territorios y comunidades conquistadas en la estructura política, cultural y socioeconómica de los conquistadores" (García Fitz, 2009, p.154); a consolidação de estruturas feudais na Península Ibérica, sobretudo fundada na feição bélica da nobreza; a operação bélica como suporte e o conteúdo ideológico (para García Fitz, desde o século IX, 2009, p.164). A Reconquista teria sido sustentada por duas colunas: a da guerra justa e da guerra santa (García Fitz, 2009, p.198).

Fitz aprecia a possibilidade de a vertente cruzadística/de um combate pela fé ter sido uma importação tardia, "do coração da Europa" para a Península. Essa questão parece próxima às tentativas de introduzir conceitos tais como os de "centro" e "periferia", absolutamente anacrônicos para o contexto medieval, ao debate (Guimarães, 2016, p.208-210). Devemos falar em acréscimos e 
transformações do conceito à luz do que propôs Koselleck (2006, p.115), ou seja, tanto a "estratificação dos significados de um mesmo conceito em épocas diferentes" quanto a "simultaneidade da não simultaneidade que pode estar contida em um conceito”. No caso, é o próprio Fitz quem evoca a noção de atividade bélica sacralizada já entre os visigodos e nas páginas das crônicas do século IX e X. Assim, na sua dinâmica de permeabilidade, a Reconquista acolheu elementos que, entretanto, estavam ou esboçados ou claramente propostos antes das Cruzadas, e esses elementos robusteceram o seu conteúdo ideológico.

A Reconquista, portanto, como feixe de relações e elementos teria se iniciado no século IX, como efeito da mobilidade dos clérigos moçárabes em contexto de enfrentamento contra as autoridades muçulmanas, ${ }^{4}$ do achamento das relíquias do apóstolo Tiago Maior e do desejo de expansão territorial dos grupos que se iam enriquecendo de elementos identitários agregadores. Ela foi a força da mobilização e do avanço em direção ao Al-Andaluz. Seu término se deu com a tomada de Granada, feito dos reis católicos Isabel e Fernando. Isabel era filha de Juan II, o "serenísimo Príncipe, segundo rey deste nombre en Castilla y en Leon" e da rainha Isabel de Portugal, esta por sua vez neta de D. João I de Portugal, conquistador da Praça de Ceuta. O fim da campanha identificada no mesmo século das fontes não significou que se vivia um arrefecimento da campanha, ao contrário, como vamos surpreender nas fontes.

À luz da documentação de que dispomos, portugueses e castelhanos tinham 2 alternativas para dar continuidade à Reconquista na primeira metade do século XV: Granada e o Magreb, sendo a primeira alternativa a mais óbvia para os agentes de então. No caso dos portugueses, Zurara põe o rei João I a imaginar a maneira como pudesse mais servir a Deus (capítulo VII); já no caso da CDJII, o primeiro elemento é o descontentamento de Fernando de Antequera com o rumo dos acontecimentos logo posteriores à morte do irmão Henrique III; seu descontentamento inclui a governação e justamente o estado da guerra contra os mouros. Ainda que fiquem evidentes as rugosidades na relação entre os regentes, a rainha Catarina e o infante, o fato é que entre os negócios que conseguem um encaminhamento mais imediato (e beneficiado pela concórdia entre ambos) sobressaem justamente os da Reconquista. Assim, no primeiro ano do reinado, em cortes, os procurados respondem afirmativamente ao pedido de recursos necessários à continuidade da campanha: 
por ensalzamiento de la Fe católica é acrecentamiento de la Corona Real del Rey nuestro senõr vuestro hijo, en querer ir personalmente en esta guerra, é tomar de tan gran voluntad empresa tan sana y tan loable; y esperamos en nuestro Señor que por sus merecimientos de dará victoria de los enemigos de nostra sacta Fe católica ... todos trabajarémos como haya efecto todo lo que por la Reyna nuestra señora, y Vuestra Señoría nos es mandado. (CDJII, p.281)

São outorgados 45 contos ao projeto, pelos quais tanto a rainha quanto o infante juram não empregar em outra intenção. Do fragmento sobressaem: a aliança entre a exaltação da fé e a glória do reino; a identificação entre inimigos do reino e da fé e o caráter didático que teria a empresa ao inflamar a vontade do rei Juan II, ainda uma criança. Anos depois desse requerimento, em 1411, os procuradores responderiam afirmativamente outra vez, reconhecendo "esta guerra santa y honesta" (CDJII, p.336).

Mesmo a rainha D. Catarina sente-se motivada a acompanhar o cunhado, no que é demovida pelo Conselho do Rei. Assim, definitivamente começa a campanha de Fernando de Antequera em 1407, com direito à colaboração de muçulmano apóstata (CDJII, p.287) e com a insistência na ideia de servir a Deus e confiança na ajuda de Deus. Nesse mesmo ano, sobressai o temor do rei de Granada em relação às forças reunidas pelo infante (CDJII, p.290) e as iniciativas defensivas dos muçulmanos para se resguardarem dos avanços cristãos (CDJII, p.291). Álvaro García de Santa María põe os muçulmanos amedrontados diante do seu senhor; descreve um infante "anojado" diante da falta de compromisso dos seus (CDJII, p.300) e o apresenta reverente diante das vitórias auferidas (CDJII, p.301). Mesmo em meio a toda a energia bélica manifesta, não pode esconder os momentos em que Fernando de Antequera se sente alquebrado ou mesmo em que é necessário recorrer às tréguas e à troca de presentes (CDJII, p.308 e 313). Vemos também pela narração de García de Santa María que a Reconquista ainda atrai nobres de outros reinos e casas senhoriais de prestígio no Ocidente Latino (CDJII, p.314 e 322). O cronista também tem conhecimento das mudanças políticas no reino de Granada, e concluímos graças à sua narrativa que, entre cristãos e muçulmanos, não era nada fácil consolidar poder político nesses tempos tardo-medievais...

Sobre a sacralidade da guerra, mas não só, em 1410 o infante Fernando de Antequera requer o pendão de Santo Isidoro: "Los Reys de Castilla 
antiguamente habian por costumbre que cuando entraban en guerra de Moros por sus personas, llevaban siempre consigo el Pendon de Santo Isidro de Leon, habiendo con él muy gran devocion" (CDJII, p.328). Uma leitura atenta vai mostrar talvez o que tenha escapado ao reverente cronista: o manifesto desejo do infante de se igualar aos reis, o que ele não era (ainda); o relacionamento do seu requerimento a um projeto maior e, como consequência, a "escrita" de seu nome na linhagem dos reis da Reconquista. Tudo, menos humilde.

Uma de suas maiores conquistas de fato é a terra que se acopla como honra a seu nome, Antequera. Assim, o cronista narra a conquista, a bênção da Mesquita, a procissão... Depois disso, um leve arrefecimento da narrativa de eventos relacionados aos mouros. O primeiro capítulo de 1412 manifesta tréguas, e depois não há mais eventos relacionados à Reconquista no ano. Por quê? Porque Álvaro García de Santa María se concentra na notícia da elevação do seu senhor à condição de rei de Aragão. A narrativa se abre também à exploração de outros assuntos, como o cisma e a sua solução no Concílio de Constança. Os mouros desaparecem do texto por ora.

Entre 1416 e 1418, o jovem rei D. Juan II perde seus tutores para a morte, e em 1419 o governo de seu reino lhe é entregue em definitivo (CDJII, p.378). O rei tem 14 anos e é logo vítima da "tutela" de seus primos, os infantes de Aragão, filhos de Fernando de Antequera. Não serão raros os momentos em que o rei precisará fugir, graças a ardis, da "proteção" dos seus ao longo de todo o seu reinado, arrojando-se em situações de grande risco. Assim, os negócios da Reconquista são eventos que se veem muitas vezes negligenciados, deixados ao léu, não em razão de uma sensação de segurança do rei, ou fadiga da campanha, ou ainda mesmo de enfraquecimento dos seus princípios no contexto. Os cronistas que dariam continuidade ao texto têm inúmeros eventos graves a tratar, e um dos mais relevantes será o conflito entre os nobres pela privança e poder junto a um rei fraco. De um lado, os infantes de Aragão: o recalcitrante D. Henrique, cunhado do rei, graças a uma verdadeira campanha de assédio junto à infanta Catarina; o rei de Aragão Afonso; o futuro rei de Navarra D. Juan (que haveria de ser, depois da morte do irmão, também rei de Aragão!); do outro lado o Condestável D. Álvaro de Luna, presença talvez mais constante ao longo de todo o reinado, o que não lhe valeu, entretanto, garantias perpétuas de segurança, pois é condenado à morte no fim da narrativa, depois do casamento entre D. Juan II e D. Isabel de Portugal, pais de Isabel a Católica. O saldo 
de negatividade pende para o Condestável, não pode pender para quem age quase igual, o rei de Aragão e Navarra também Juan II, pai de Fernando Católico. Se pendesse, dificilmente esse texto encontraria guarida na câmara da rainha Isabel.

Granada não é, entretanto, totalmente esquecida, vez por outra é envolvida nos conflitos entre os privados do rei de Castela; vez por outra o rei cristão interfere na sucessão desse reino mouro, enviando mesmo embaixadores ao Magreb; vez por outra ainda, quando consegue apascentar os nobres do seu reino, o rei pode rumar em direção às fronteiras de Granada e conquistar algumas vitórias, mas esses acontecimentos episódicos não podem ser comparados ao contexto belicista da regência de Fernando de Antequera. O contexto instável em Castela, do reinado efetivo de D. Juan II, também não escapa aos mouros que, por sua vez (CDJII, p.654), fazem entradas pelo reino e causam danos a diversas partes. O fato é que a CDJII é uma crônica imensa, repleta de acontecimentos e perspectivas (também em razão de ter sido escrita por diferentes agentes). Álvaro García de Santa María escreveu sobre o que viu e talvez tenha tomado parte junto a Fernando de Antequera; os outros cronistas, mais envolvidos nas disputas internas em Castela, de graves consequências, não deixaram de narrar a Reconquista, mas tiveram de trazer para o texto as dificuldades do governo de D. Juan II, que foram maiores entre os seus próximos e privados.

Fernão Lopes também narra os desafios do governo de D. João I. Armindo de Sousa divide o reinado desse rei em dois momentos: uma primeira fase até 1412 e outra até o final, em 1433 (Mattoso; Sousa, 1993, p.498). Portanto, findo o período em que "andou-se praticamente em guerra" (Mattoso; Sousa, 1993, p.497), o rei tem um "problema": a paz. Quando a paz é um problema no medievo? Quando as gentes belicosas abundam sob o mesmo teto. O que fazer? Dar-lhes motivação legítima para a continuidade de seu modo de viver. Fernando de Antequera demove o rei de Portugal de seu intento de fazer guerra aos mouros de Granada. Como monarca "batizado" no campo de São Jorge, D. João tinha "grande vontade de fazer seus filhos cavaleiros o mais honradamente que se bem pudesse fazer" (CTC, p.55), mas justamente pela trajetória do pai, os filhos haveriam de querer corresponder-lhe em feitos, não em festejos. O projeto de Ceuta nasce, portanto, de uma convergência: do desejo dos infantes de uma obra notável e de uma sugestão, do vedor da fazenda de D. 
João I, João Afonso: "Vossos pensamentos, disse ele, são assaz de grandes e bons e, pois que vos tal vontade tendes, eu vos posso assinar uma cousa em que o podeis bem e honradamente executar. E isto é a cidade de Ceuta que é em terra de África que é uma mui notável cidade e mui azada para se tomar" (CTC, p.57).

$\mathrm{O}$ rei D. João I, entretanto, reage com pouca gravidade à sugestão dos infantes. Ri, mas Zurara não identifica esse riso com sarcasmo ou ironia. Nisso segue a Fernão Lopes, que põe o monarca algumas vezes a rir, e até de si mesmo. Ouro traço de personalidade revelado na narrativa, em convergência à narrativa de Lopes, é a hesitação de D. João I. Os leitores da crônica lopeana vão se lembrar das hesitações do então mestre de Avis na crise de 1383-1385. D. João I não sobressai na narrativa do primeiro cronista português na função como um usurpador, é um rei que se fez, portanto suas hesitações são ressignificadas sob o signo da cautela. Para uma geração que aprende e valoriza o regime das letras, a convocação dos letrados para o entendimento do projeto de Ceuta não é uma surpresa também.

Os ardis do rei, de falsas embaixadas, contendo propostas de casamento mirabolantes para os filhos; a espionagem da volta dessa embaixada, que passa por Ceuta, e o segredo no reino ao longo da preparação do evento compõem o quadro, sem sombra desabonadora para Portugal. Ainda que os portugueses e castelhanos vivessem tempos de trégua, os agentes da época não poderiam ter a presciência de que não haveria uma mudança repentina de acontecimentos. Portugal observava o alçamento de Fernando de Antequera à condição de rei de Aragão, e este observava Portugal, tanto que envia embaixadas que manifestam preocupação com aquilo que mal se esconde: Portugal está a preparar uma grande campanha militar (CTC, p.130). Essa movimentação atrai mesmo agentes de fora da Península, como um duque alemão e um barão (CTC, p.130).

Um dos aspectos dignos de nota na preparação da campanha de Ceuta é certamente a posição da rainha Filipa de Lencastre (lembremo-nos que sua irmã, Catarina de Lencastre, rainha de Castela, aventou a possibilidade de acompanhar o cunhado na campanha contra Granada). D. João I tem uma expectativa que se frustra no encontro entre os esposos: achava que ela lhe rogaria que não desse ensejo à demanda dos filhos. Na verdade, ela estimula o projeto, só manifesta o senão em relação à presença do rei no 
empreendimento. Há dois gestos muito relevantes protagonizados pela rainha para a inserção dessa campanha dentro da agenda da Reconquista: a repartição da relíquia do Santo Lenho e a confecção das espadas, com as quais ela presenteia os filhos: "Meus filhos" - disse ela - "eu vos rogo que vós recebais esta preciosa joia, que vos dou com grande devoção ... quem nela tem verdadeira feuza cobra escudo firme e forte para sua defensão contra o qual não pode empecer nenhum inimigo espiritual nem temporal, especialmente contra os infiéis" (CTC, p.152).

Esse "talismã" tem especial poder contra os infiéis. Depois da repartição, a rainha dá a sua bênção aos filhos. O cronista afirma que os infantes conservaram a relíquia sempre junto a si, com um sutil desmerecimento do infante Pedro, pois o cronista só supõe que o Duque de Coimbra tivesse a relíquia no máximo apreço. Na CTC, o infante D. Henrique, que fica ao lado do sobrinho em Alfarrobeira, é o herói da narrativa. Ele ocupa a posição de prestígio análoga à de Fernando de Antequera na primeira parte da CDJII.

A CTC tem 105 capítulos, e Zurara compreende a metade da narrativa para a preparação e a outra metade se refere à viagem e à conquista em si. No capítulo 51, D. João I reza: "Praza-Te por Tua santa mercê, que Te nembres de mim e deste Teu povo, de que me deste encargo que somos aqui ajuntados para fazer Teu santo serviço e nos queirais dar vitória contra os inimigos da Tua Santa Fé, guardando a satisfação de nossos pecados para outro tempo" (CTC, p.179).

Ainda haveria a pregação de Fr. João Xira que anuncia e publica uma bula papal que reconhece o status de cruzada para a campanha. Três anos depois, D. João I escreveria ao papa com pedido de uma bula de cruzada. João Luís Inglês Fontes afirma:

É curioso verificarmos que, na súplica de D. João I ao papa Martinho V, aparece-nos claramente a consciência de que a manutenção da cidade, se serve a Cristandade e a exaltação da fé por estender o seu domínio territorial ao Islão, serve também os interesses expansionistas nacionais, aplicando-se igualmente a esta atividade as indulgências e privilégios concedidos aos cruzados que iam para a Terra Santa. (Fontes, 1995, p.406)

O papa concede algumas bulas, que manifestam o direito de Portugal sobre Ceuta e outras cidades; o convite à participação dos cristãos contra os 
“infiéis” em África; a elevação de Ceuta a cidade e da mesquita a Sé (Fontes, 1995, p.407). Assim, não há sombra de dúvida sobre como a campanha foi concebida e reconhecida em sua época, ou seja, não só como capítulo da Reconquista, mas como Cruzada, quer seja pela crônica régia, quer seja pelos documentos pontifícios aludidos.

\section{A vitalidade da Idade Média em nossas salas de aula}

Neste segmento, faremos menção a três elementos que podem ser particularmente instigantes para o estudo da Idade Média em sala de aula. O primeiro tem a ver com a exploração da datação, o segundo com a narrativa, e o terceiro com uma reverberação da Reconquista no Brasil. ${ }^{5}$ Ao final, esboçaremos uma proposta de trabalho para ser desenvolvida em sala de aula, nas últimas séries do Ensino Fundamental ou ao longo do Ensino Médio, dependendo da construção da grade escolar.

No caso da datação, a partir da definição de uma data - aqui foi 1415 -, é possível explorar redes de relações. Não se trata de ressuscitar as velhas cronologias, mas buscar perceber que os eventos históricos não estão isolados. Assim, a movimentação em Portugal que antecedeu a campanha efetiva de Ceuta inquietou a Fernando de Antequera (em Aragão) que, por sua vez, já rei, ainda haveria (no mesmo ano de 1415) de tentar colaborar para a solução de um problema mais "global" no contexto, o Cisma. Com a proposição de um ano, vale convidar os estudantes a perceberem eventos relacionados, como em contatos sinápticos.

No caso das crônicas régias medievais, é preciso lembrar que elas já foram detratadas como narrativas autorizadas e legitimadoras dos comitentes. Essa documentação foi também detraída pela historiografia que não via possibilidade de dissonância no projeto legitimador que enceta esses textos. Nas últimas décadas, porém, ainda que muitas vezes continuem a ser concebidas como expediente de propaganda dos monarcas medievais, os historiadores têm ensaiado novas questões para os textos. Os estudos sobre narrativa, como os realizados por Paul Ricoeur e Jörn Rüsen, têm beneficiado o debate, ao reconhecerem/valorizarem as operações racionais de sentido que urdem os textos narrativos. Esse debate tem feito os historiadores voltarem sua atenção à maneira, não apenas aos fatos que compõem o enredo, mas às escolhas, 
intenções, julgamentos, intertextualidades, equilíbrio entre os assuntos na narração dos acontecimentos, ao modo de narrar, portanto. ${ }^{6}$

O primeiro contato com uma crônica medieval não deve temer o estranhamento, afinal Georges Duby já nos alertou sobre o valor da diferença, que nos ensina mais que as analogias (Duby, 1998, p.13). O estranhamento da linguagem e do modo de narrar nos convida a perceber outro mundo, diverso do nosso, que entretanto nos constitui. Esclarece escolhas feitas no passado, à luz de condições muito diversas das que vivemos. A percepção da singularidade amplia a nossa capacidade de compreensão da diferença.

A Reconquista como feixe de relações e elementos, iniciada no século IX e concluída no século XV, é um dos grandes alicerces do medievo ibérico. Como a sua temporalidade quase se identifica com o que chamados de Idade Média, depois da Antiguidade Tardia, não se pode ensombrar a importância desse movimento no contexto. Daí ser tema fundamental para compreendermos a formação dos reinos ibéricos, que iniciaram a expansão ultramarina. Um dos veículos de percepção paulatina da configuração desses reinos está inscrito justamente nas crônicas medievais. Por que o projeto da crônica geral se esgotou? Porque ele não se coadunava mais com o fortalecimento das monarquias em seu desejo de resguardar a própria independência (Guimarães, 2012c, p.66-70).

Depois de uma incursão na diferença do texto, no impacto com a sua linguagem, é fundamental "decodificá-lo", para que os estudantes possam compreendê-lo. O professor deve ser o guia para a compreensão dos universos que os aprendizes ainda ignoram. Nesse sentido, não basta traduzir, mas explorar o léxico, as formas de tratamento, as promessas, valores e compromissos estabelecidos. Tratamos de crônicas, portanto, de narrativas autorizadas, cuja seleção de eventos obedeceu a critérios específicos radicados na autoridade, seja ela das fontes usadas, seja do projeto que ela encerra. Assim, vale tanto ler o que está escrito quanto o que está sugerido, e não descurar do que não foi dito! Zurara refere uma série de eventos sucedidos em 1415, que incluem a presença de castelhanos em Portugal e que simplesmente não são referidos na CDJII. Onde está a verdade? Nesse caso específico, na exploração de outros documentos, mas certamente na diferença de objetivos dos textos. As fontes estão cheias de respostas, é preciso que os estudantes aprendam a fazer as perguntas. O que queremos saber? As narrativas vão contar muitos segredos aos 
jovens historiadores e vão contar, sobretudo, formas com as quais as sociedades ordenaram os acontecimentos vividos e os compreenderam. A sua compreensão da vida é tão importante (ou mais?) quanto a sequência de fatos sucedidos.

Uma das formas de se perscrutar as intenções pretendidas das crônicas medievais é a leitura atenta de seus prólogos. Ali está revelada uma série de relações aprovadas no contexto. O prólogo encerra um conjunto de crenças. Nem sempre as crônicas que nos chegaram alcançaram o presente com seus prólogos, isso vai exigir dos historiadores que recolham ao longo do texto essas intenções. Na CTC, o capítulo 1 consigna um rol de intenções, mas não só: ele é urdido com um elemento essencial desse tipo de texto: a voz de autoridade. Zurara cita Aristóteles na primeira frase! Depois se apega ao texto bíblico para explicar a seus leitores o quanto devem ter confiança na graça de Deus. Por que faz isso? Porque seu prólogo é um pedido - pedido para que seja capaz de narrar. Lemos esse aspecto como uma espécie de invocação cristianizada, parente afastada de uma das partes da epopeia. Lembremo-nos que também as epopeias são textos narrativos. Sobre a matéria narrada, esse capítulo/prólogo fala muito pouco em si! Outro detalhe importante ainda sobre a voz de autoridade é a presença da voz de Avicena (980-1037), médico muçulmano que já se havia convertido em autoridade no mundo cristão!

A crônica compilada por Fernán Perez de Guzman também tem um prólogo. As vozes de autoridade (embora diversas) aparecem no segmento. $\mathrm{O}$ cronista afirma que tão importante quanto salvar os acontecimentos dignos de boa memória - refere-se a conquistas para dar exemplos às gerações -, é fundamental que os príncipes saibam, portanto, leiam essas narrativas. Levando-se em conta as incríveis dificuldades que Juan II enfrentou no seu reinado, esse aviso do cronista ganha muita ressonância. Outro detalhe importante, a que Zurara só faria referência depois, tem a ver com a forma como o cronista trabalhou: consignou o que testemunhou, mas sobre tudo aquilo que não viu nutriu-se do testemunho de "hombres prudentes muy dignos de fé" (CDJII, p.277).

Tudo aquilo que afirmamos sobre a "documentação", item 1, é essencial à exploração da crônica medieval. Quando sabemos quem é o cronista, devemos explorar quem ele é. Quando não sabemos, devemos recolher pistas ao longo do texto, não tanto com a intenção de identificá-lo sem margem de 
erro, mas com a intenção de perceber quem poderia ter sido - um clérigo, um letrado laico, nobre etc., levando-se em conta seus comentários sobre a matéria narrada (a narração em si), ou mesmo seu repertório. Outras questões essenciais: para quem escreve? Em que circunstâncias? Contexto? Fernão Lopes, Pero López de Ayala, Álvaro García de Santa María, Fernán Perez de Guzman e Gomes Eanes de Zurara são cronistas muito diferentes. Ainda que recorram aos trabalhos um dos outros, fazem isso imprimindo marcas muito diversas e autorais nos seus textos, como vimos.

Em relação ao terceiro tema, a reverberação da Reconquista no Brasil, é fascinante abordar o que se constitui em nosso país como presença. Referimo-nos obviamente às Cavalhadas. ${ }^{7}$ São uma das mais espetaculares ressignificações operadas do que no passado foi luta e tragédia e hoje é alegria e festa. Como assim? A luta real entre cristãos e mouros que podemos conceber como elemento fundamental do medievo ibérico é hoje uma tradição festejada (!) em cidades brasileiras. Gerações de rapazes têm se sucedido como "mouros" e “cristãos", mobilizado as famílias para a confecção de ricas indumentárias, têm ensaiado e se esforçado para se enfrentarem em provas de destreza, a cavalo, cujo encerramento é a consolidação da cordialidade e a manifestação da alegria coletiva, que, por sua vez, promove os vínculos na comunidade. Em Pirenópolis (GO), Guarapuava (PR), Brumal (MG) e em outras tantas cidades e distritos brasileiros, turistas prestigiam o evento, movimentando até mesmo a economia local. Como afirmar, portanto, que a Idade Média nos é estranha, se essa tradição é presença mais representativa aqui que nos países em que se deu a Reconquista?

A transformação significativa do tema da Reconquista no Brasil, do feixe de elementos e relações perpassado pela violência na Idade Média em experiência lúdica, colabora para a compreensão de que a História não compreende uma narrativa determinista. O estudo da "ciência dos homens no tempo" (Bloch, 2002, p.55) revela que o que nos atrai é a mudança. Da experiência medieval, podemos analisar a transferência para o Brasil, a relação da festa com a Festa do Divino e a permanência e sucesso no presente. Um debate pode ser realizado a respeito do que colabora para esse êxito em nossos dias. O cinema, os jogos e a literatura são aliados dos estudos medievais, não porque são pesquisa histórica - podem se nutrir da pesquisa histórica certamente -, mas 
porque despertam o interesse das gerações para o estudo, que deve articular pergunta e documentação.

\section{Esboço de uma proposta:}

1. Seguindo a proposta do estranhamento e da diferença que mais nos ensina, pode ser uma boa estratégia a distribuição de fragmentos (iguais ou diferentes) não muito longos das crônicas, previamente selecionados pelo professor, tanto em português quanto em castelhano, a grupos de três estudantes. O critério de escolha dos fragmentos pode ser a unidade de sentido: um exemplo do cronista, uma situação inteira, a declaração completa de um personagem. Esses fragmentos vão impactar a turma como uma espécie de carta cifrada. O desafio poderia ser a descoberta do maior conjunto de informações. Cada grupo faz seu registro.

2. Em um segundo momento, o professor distribui uma versão em português contemporâneo do fragmento, para que os grupos confiram seus registros. Essa etapa é a da decodificação. Seu objetivo é ampliar a compreensão do trecho selecionado.

3. Depois do entendimento do fragmento, vale a pena fazer um convite ao professor de língua portuguesa e, se possível, ao de língua espanhola para a exploração do português arcaico e do castelhano arcaico. O colega da área de Letras pode ressaltar que ambas as línguas se aproximavam muito no medievo.

4. Cumpridas as etapas de estranhamento, decodificação e enriquecimento com a percepção histórica das línguas, vale a pena incrementar o estudo com a visualização de imagens: pinturas, exemplos da arquitetura, do políptico de São Vicente pintado por Nuno Gonçalves, por exemplo, que apresenta alguns dos personagens que estão na Crónica da Tomada de Ceuta.

5. Uma próxima etapa pode ser vivenciada com a leitura dos prólogos de ambas as crônicas. O professor primeiro apresenta os textos originais, depois a versão em português contemporâneo e, em grupos, os alunos apontam elementos convergentes e divergentes entre os prólogos de 
Zurara e dos autores da Crónica del serenísimo Príncipe Don Juan, segundo rey deste nombre en Castilla y en Leon.

6. Para enriquecer essa etapa, o professor pode apresentar alguns esboços biográficos de alguns cronistas medievais e pode provocar os estudantes a pensarem a respeito da diferença do fazer histórico, em relação ao nosso presente. Se no medievo a História foi escrita por monges e depois por cronistas que viviam sob a proteção de grandes senhores e que escreviam segundo os projetos encetados também por esses comitentes, onde e quem escreve a História hoje? Essa escrita é realizada sob a proteção de alguém? Vale a pena abordar o que é a pesquisa histórica e onde ela é realizada.

7. A fim de discutir especificamente o tema da Reconquista, é preciso voltar à documentação e fazer nova seleção de fragmentos que deem conta: das motivações dos agentes para empreender a campanha; da forma como o cronista aprova a luta armada para vencer o "inimigo" e de como esse "inimigo" é descrito. Este artigo pode ajudar com a seleção de exemplos!

8. A fim de que os estudantes percebam as transformações do tema da Reconquista e a sua vitalidade histórica, vale a pena realizar uma pesquisa sobre as cavalhadas, escolhendo um município brasileiro em específico. Os alunos terão de pesquisar quando a festa foi introduzida no município; como ela vem se transformando; podem realizar entrevistas (in loco, ou por Skype); ouvir seus participantes e averiguar se percebem o lastro histórico da prática lúdica a que se entregam. Hoje, mouros e cristãos são vizinhos, e sua luta estreita os laços na comunidade.

9. A última etapa pode ser a escrita de uma nova "crônica histórica", com prólogo e tudo, cuja matéria será o desdobramento da Reconquista nas cavalhadas: uma história de paz no Brasil. Se houver condições, é possível discutir que formato essa "crônica" pode ter no presente: um texto?; um vídeo feito com o celular? Novas formas de "escrita" da História! Mas a turma também pode selecionar outros fatos importantes para a escrita da História hoje. 


\section{Considerações finais (parciais)}

Abrimos este ensaio com a alusão a uma solução temporária para a guerra na Idade Média, ou seja, com tréguas, que foram celebradas entre Portugal e Castela, e o fechamos qualificando o "final" como "parcial". Portanto, na apresentação da pesquisa histórica, reconhecemos o caráter não definitivo, nem das decisões que foram tomadas pelas sociedades que nos antecederam (no contexto em que o foram), nem do trabalho do historiador. Mesmo assim, assumimos a necessidade de tomar posições. Não há contradição, há um regime de sinceridade que pode ser um bom ponto de partida para os estudantes. O provisório não é frustrante, é convidativo. Assim, o debate sobre a historiografia, à luz das colaborações de outros historiadores, definiu um conceito. Também à luz da leitura atenta às fontes, percebemos a vitalidade do tema no século XV, na reunião de elementos já dilatados no tempo e na permeabilidade do projeto, passível de transformações na diacronia. Sem ter sido identificada na origem com a Cruzada, no século XV a Reconquista é reclamada como tal pelo rei D. João I; este solicita bulas ao papa, que lhe são outorgadas.

No último ano da CDJII há um claro posicionamento de D. Juan II sobre o avanço da campanha portuguesa em África. Há uma mobilização do rei de Castela, que institui procuradores para tentar impedir esse avanço. Quando esse gesto é narrado, muito já se havia realizado e vivido: os portugueses haviam ultrapassado o Cabo Bojador (1434), já haviam sofrido a derrota em Tânger (1437) e já haviam chegado à Guiné (1446). D. Juan II se inquieta e insta seus procuradores a comunicarem aos portugueses que a Guiné era sua (CDJII, p.692).

$\mathrm{O}$ ano de 1415 foi também um ponto de partida para o ensaio, afinal identificado com a conquista da Praça de Ceuta pelos portugueses. Mas esse ano também revelou a pouca expressão que o feito teve na crônica castelhana. Um disfarce? Talvez, mas pode ser ainda mais que isso. Embora as duas narrativas sejam crônicas régias, a portuguesa é uma crônica em cuja essência há um acontecimento fulcral, enquanto na castelhana há a necessidade de narrar quase 50 anos de um reinado muito complexo. Na economia do texto compilado e encerrado por Fernán Perez de Guzman devem caber muitos acontecimentos. A leitura de todos eles diz muito sobre os desafios da monarquia 
nesses tempos tardo-medievais. Mas a obra desses cronistas revela, ainda, a transformação do próprio gênero textual, da crônica geral às crônicas régias e particulares.

As questões tanto sobre a documentação quanto sobre o tema da Reconquista encontram grande potencial na curiosidade dos jovens. A cultura de massa pode ser aliada, se não cobrarmos dela aquilo que não é seu objetivo. A pesquisa histórica é trabalho dos historiadores que podem, por sua vez, também colaborar com jogos, peças de teatro, filmes etc. Ensaiamos uma discussão em níveis para o universo da sala de aula: o ano, a narrativa e a transformação do acontecimento. Os níveis são historiográficos: os eventos em rede evidenciam impactos; a narrativa nos leva a compreender como as sociedades deram sentido a experiências várias, e as Cavalhadas nos permitem analisar a transformação de uma experiência medieval plural, atravessada pela vertente bélica da nobreza, em experiência lúdica, que colabora para a consolidação dos vínculos nas comunidades que se entregam à prática.

Nestes tempos em que pelo mundo se discute o papel das humanidades, ${ }^{8}$ vale a evocação:

A História todo dia me ensina que somos sobreviventes. Para mim a História continua sendo a 'mestra da vida'? Não. De antemão, não posso afirmar o que pressupõe a questão, porque isso seria vincular a História hoje à especificidade de como era compreendida na Antiguidade e também na Idade Média ...

Ser sobrevivente me vincula à teimosia da vida. A História me dá esperança, porque me mostra que mulheres e homens lutaram por ideais que, por sua vez, foram ultrapassados; que estavam dispostos a tudo o que... afinal mudou por completo! O estudo da História Medieval me revela, por exemplo, que foi possível fazer a paz, quando tudo lhe parecia contrário; que impérios magníficos foram dilacerados; que cidades que sofreram as maiores pilhagens, três dias depois, ergueram-se com novos nomes e quem as ergueu foi gente. A História põe meus pés no chão, quando o desespero ameaça. (Oliveira; Guimarães, 2016, p.17)

O conhecimento histórico combate ainda o imobilismo.

Vale lembrar que, ao longo desses 6 séculos em que compreendemos a Reconquista, cristãos e mouros nem sempre estiveram em lados opostos. Foram aliados também. Essa complexidade estimula e os documentos analisados mostram alguns exemplos disso, que, entretanto, não têm espaço para 
serem explorados aqui. Vale o convite. Nem só de guerra vive a narrativa. Nela também cabe e sempre caberá a paz, mesmo que em forma de tréguas, uma outra solução temporária...

\section{REFERÊNCIAS BIBLIOGRÁFICAS:}

ALVAR, Carlos; MAINER, José-Carlos; NAVARRO, Rosa. Breve Historia de la Literatura Española. Madrid: Alianza Editorial, 2011.

BLOCH, Marc. Apologia da História ou o ofício de historiador. Trad. André Telles. Rio de Janeiro: Jorge Zahar, 2002.

DUBY, Georges. Ano 1000 Ano 2000: na pista de nossos medos. Trad. Eugênio Michel da Silva e Maria Regina Lucena Borges-Osório. São Paulo: Ed. Unesp, 1998.

FLETCHER, Richard. Em busca de El Cid. São Paulo: Ed Unesp, 2002.

FONTES, João Luís Inglês. Cruzada e expansão: a bula Sane Charissimus. Revista Lusitânia Sacra, 2a série, v.7, p.403-420, 1995. Disponível em: http://repositorio. ucp.pt/bitstream/10400.14/4952/1/LS_S2_07_JoaoLIFontes.pdf; Acesso em: 24 abr. 2017.

FUNES, Leonardo. Elementos para una poética del relato histórico. In: ARIZALETA, Amaia (Éd.) Poétique de la chronique: l'écriture des textes historiographiques au Moyen Âge (péninsule Ibérique et France). Toulouse: Université de Toulouse-Le Mirail, 2008. (Coll. Méridiennes).

GARCÍA FITZ, Francisco. La Reconquista: un estado de la cuestión. Revista Clio \& Crimen, v.6, p.142-215, 2009. Disponível em: https://www.durango-udala.net/portalDurango/RecursosWeb/DOCUMENTOS/1/1_1945_3.pdf; Acesso em: 24 abr. 2017.

GONZÁLEZ JIMÉNEZ, Manuel. Sobre la ideologia de la Reconquista: realidades y tópicos. In: SEMANA DE ESTUDIOS MEDIEVALES, 13. Nájera: Instituto de Estudios Riojanos, 2003. Disponível em: http://www.vallenajerilla.com/berceo/ santiago/reconquista.htm; Acesso em: 24 abr. 2017.

GUIMARÃES, Marcella Lopes. Capítulos de História: o trabalho com fontes. Curitiba: Aymará, 2012a.

A coleção de cartões postais do historiador. Revista Brathair, São Luís: Uema, v.16, n.2, p.205-220, 2016. Disponível em: http://ppg.revistas.uema.br/index.php/brathair/article/view/1261; Acesso em: 24 abr. 2017.

. Crônica de um gênero histórico. Revista Diálogos Mediterrânicos, Curitiba: UFPR, v.2, p.67-78, maio 2012b. Disponível em: http://www.dialogosmediterranicos.com.br/index.php/RevistaDM/article/viewFile/23/65; Acesso em: 13 jul. 2017. 
GUIMARÃES, Marcella Lopes. O discurso cronístico e a narratividade histórica. In: NASCIMENTO, Renata C. S.; MARCHINI NETO, Dirceu. A Idade Média: entre a História e a Historiografia. Goiânia: Ed. PUC-GO, 2012c. p.53-77. As intenções da escrita da História no outono da Idade Média. In: TEIXEIRA, Igor; BASSI, Rafael (Org.) A escrita da História na Idade Média. São Leopoldo (RS): Oikos, 2015. p.76-89.

IPHAN. Festa do Divino Espírito Santo - Pirenópolis, GO. (Dossiê). Brasília, s.d. Disponível em: http://portal.iphan.gov.br/uploads/ckfinder/arquivos/Dossie_festa_\%20do_divino_pirenopolis.pdf; Acesso em: 24 abr. 2017.

KOSELLECK, Reinhart. Futuro passado: contribuição à semântica dos tempos históricos. Apresent. Marcelo Jasmin. Rio de Janeiro: Contraponto; Ed. PUC-Rio, 2006.

LANCIANI, Giuseppe; TAVANI, Giulia (Org.) Dicionário da Literatura Medieval Galega e Portuguesa. 2.ed. Trad. José Colaço Barreiros e Artur Guerra. Lisboa: Caminho, 2000.

NUSSBAUM, Martha. Sem fins lucrativos: por que a democracia precisa das humanidades. São Paulo: Martins Fontes, 2015.

OLIVEIRA, Jelson; GUIMARÃES, Marcella Lopes. Diálogo sobre a alegria: entre a Filosofia e a História. Curitiba: PUCPRess, 2016.

RICOEUR, Paul. Tempo e Narrativa. 3v. São Paulo: WMF Martins Fontes, 2010.

SCHMIDT, Maria Auxiliadora; BARCA, Isabel; MARTINS, Estevão de Rezende (Org.) Jörn Rüsen e o ensino de História. Curitiba. Ed. UFPR, 2010.

SILVA, Mônica Martins. A Festa do Divino: Romanização, Patrimônio \& Tradição em Pirenópolis (1890-1988). Dissertação (Mestrado em História das Sociedades Agrárias) - UFG. Goiânia, 2000. Disponível em: https://pos.historia.ufg.br/ up/113/o/SILVA_M_nica_Martins_da._2000.pdf; Acesso em: 24 abr. 2017.

\section{Documentos:}

Crónica del serenísimo Príncipe Don Juan, segundo rey deste nombre en Castilla y en Leon. In: Biblioteca de autores españoles desde la formación Del lenguaje hasta nuestros dias. Cronicas de los reyes de Castilla desde Don Alfonso el Sabio, hasta los católicos Don Fernando y Doña Isabel. Colección ordenada por Don Cayetano Rosell. Tomo II. Madrid, 1953.

ZURARA, Gomes Eanes de. Crónica da Tomada de Ceuta. Introdução e notas de Reis Brasil. Sintra: Publicações Europa-América, 1992. 


\section{NOTAS}

${ }^{1} \mathrm{Na}$ chamada Crônica do infante santo. Destacamos dois especialistas brasileiros no tema do infante santo: Clínio Amaral (UFRRJ) e Renata Cristina de Sousa Nascimento (UFG/ UEG/PUC-GO).

${ }^{2}$ Sobre a escrita da História no contexto tardo-medieval, entre Ocidente e Oriente, sugerimos: GUIMARÃES, 2015.

${ }^{3}$ Além de crônicas régias, Ayala escreveu o Rimado de Palácio.

4 "As comunidades cristãs que continuaram a viver sob o domínio islâmico, em Al-Andaluz, eram conhecidas como moçárabes. No meado do século IX, um certo número de moçárabes de Córdoba, preocupados com a crescente atração exercida sobre seus correligionários pela cultura árabe e pela fé islâmica, buscou o martírio de forma deliberada, insultando em público o Profeta e seus ensinamentos" (FLETCHER, 2002, p.29).

${ }^{5}$ Sobre a abordagem das crônicas em sala de aula, sugerimos: GUIMARÃES, 2012a. Essa obra foi selecionada em 2013 no PNBE (Programa Nacional Biblioteca na Escola) e foi distribuída pelo Governo Federal para incrementar a biblioteca do professor. Ela ainda contempla a exploração da cultura material, de álbuns de família, cadernos de receita e a literatura.

${ }^{6}$ No caso de Paul Ricoeur, sugerimos a trilogia Tempo e Narrativa (RICOEUR, 2010). No caso de Rüsen, indicamos a coletânea organizada por SCHMIDT; BARCA; MARTINS (2010).

${ }^{7}$ Sobre as Cavalhadas, há uma série de materiais muito interessantes, dos quais destacamos: IPHAN, s.d. e SILVA, 2000. Destaco ainda a recente reportagem sobre as cavalhadas de Brumal, publicada no blog Literistórias: http://literistorias.blogspot.com.br/2017/07/as-cavalhadas-do-distrito-de-brumal.html; Acesso em: 13 jul. 2017.

${ }^{8}$ Destacamos a instigante e esclarecedora obra NUSSBAUM, 2015.

Artigo recebido em 28 de abril de 2017. Aprovado em 17 de julho de 2017. 